\title{
НІКОЛА С.О.
}

аспірантка

Одеський начіональний університет імені I.I. Мечникова

вул. Дворянська, 2, м. Одеса, Україна, 65023

E-mail:lifesve@gmail.com

\section{ТЕОРІЯ ПРОВЕДЕННЯ ТЕНДЕРІВ СТИМУЛЮВАННЯ ЕКОЛОГООРІЕНТОВАНОГО БІЗНЕСУ}

У статті розглядаються теоретико-методологічні основи проведення тендерів з метою стимулювання екологоорієнтованого бізнесу. Розкрито сутність державного стимулюючого тендера для впровадження бізнесу з урахуванням екологічної складової, який повинен охоплювати підприємства різних районів України. Визначено мету тендеру, яка полягає в регулюванні державою організації економіко-екологічного стимулювання суб'єктів підприємницької діяльності, яким доцільно виділяти кошти для здійснення природоохоронної діяльності. Визначено умови тендеру які затверджуються тендерним комітетом до оголошення про тендер і є обов'язковими для виконання його учасниками. Під час вивчення, оцінки заявки на участь в тендері, тендерний комітет має право вимагати від претендентів додаткову економіко-екологічну інформацію, яка характеризує можливість учасників тендера освоювати виділені державою кошти на природоохоронні заходи, передбачені тендерною документацією.

Ключові слова: теорія тендерів, державне управління, стимулювання розвитку екологоорієнтованого бізнесу, критерії проведення тендера, екологічний тендер, економіко-екологічна інформації.

NIKOLA S.O.

Graduate student

Odessa National University named after I.I. Mechnikov

Street Dvoryanskaya, 2, city of Odessa, Ukraine, 65023

E-mail:lifesve@gmail.com

\section{TENDERS THEORY FOR STIMULATION ECOLOGICAL-ORIENTED BUSINESS}

The article deals with the theoretical and methodological foundations for holding tenders in order to stimulate the environmentally oriented business. The essence of the state stimulating tender for the introduction of business, taking into account the ecological component, which should cover enterprises of different regions of Ukraine, is considered. The purpose of the tender is defined, which is to regulate the state organization of economic and environmental incentives for business entities, which should allocate funds for the implementation of environmental activities. The principles for the implementation of state tenders to stimulate environmental activities conducted by an environmentally-oriented business are: fair competition among participants; maximum savings and efficiency; openness and transparency at all stages; non-discrimination of participants; objective and unbiased evaluation of tender bids; preventing collusion, corruption and abuse. Depending on the way of carrying out state bidding, on stimulating enterprises of eco-oriented business, there are: open; open with prior qualification; trades with limited participation; two-stage bidding; request procedures for the amount of incentive financing. The terms of the tender, which are approved by the tender committee prior to announcement of the tender and are obligatory for its participants to be fulfilled, are determined. In examining, evaluating an application for participation in a tender, the Tender Committee has the right to demand additional economic and ecological information from the applicants, which characterizes the opportunity of renderers' to develop state-funded funds for environmental protection measures provided for in the tender documentation. The financing of the tender is carried out at the expense of state funds and funds of the applicants who wish to take part in the tender. The size of the payment for participation in the tender is determined by the working group and approved by the tender committee together with the estimate for the organization and holding of the tender. These funds are sent to a separate account of the tendered and are used for payment of press releases, premises rent, business trips, communications, development, coordination, reproduction, translation of documents, negotiations, conferences, etc.

Key words: theory of tenders, public administration, stimulation of environmentally oriented business, tender criteria, environmental tender, economic and environmental information.

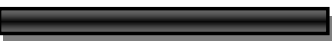

Економічні інновації

Випуск №65
ए 
Постановка проблеми та її зв'язок з важливими науковими та практичними завданнями. Основною метою організації екологічних торгів $є$ підвищення ефективності використання природних ресурсів, техніки екологічного призначення, екологічно чистих технологій, товарів і послуг, проведення програм 3 оздоровлення навколишнього середовища (програм 3 екологічної безпеки, спрямованих на зниження ймовірності виникнення екологічно небезпечних ситуацій, зменшення масштабів їх впливу і забезпечення безпеки довкілля).

В процесі тендеру екологічного спрямування (екологічного тендера) вирішуються питання залучення консультантів на основі конкуренції між оферентами (подача пропозицій учасниками), а також досягнення мінімального рівня вартості контракту (для обладнання, товарів, послуг і робіт екологічного призначення) і вибору найбільш сприятливих умов контракту ( при використанні природних ресурсів і економіко-екологічних програм). Таким чином, тендер або торги - це порядок здійснення конкурентного відбору виконавців щодо закупівлі товарів, виконання робіт, надання послуг.

Аналіз останніх публікацій по проблемі. В Україні в зв'язку з постійним збільшенням ролі конкурсних торгів (тендерів) та з метою раціонального використання бюджетних коштів та іноземних кредитів була розроблена законодавча база, якою регулюється проведення тендерів. Чинне законодавство України в сфері проведення тендерів базується на Положенні про порядок організації та проведення міжнародних торгів (тендерів) у сфері державних закупівель товарів (робіт, послуг) іноземного походження, затвердженому постановою Кабінету Міністрів України від 28 червня 1997 року № 694 [1].

На сьогоднішній день в рамках Закону України "Про здійснення державних закупівель", який вступив в силу 30.07.2010 і Положень про порядок організації та проведенні міжнародних конкурсних торгів (тендерів) [1,2,3] розглядається проведення торгів (тендерів) природних ресурсів (зокрема - надр), техніки і технології екологічного призначення, економіко-екологічних програм. Рядом авторів розглядаються економічні інструменти стимулювання природоохоронної діяльності та охорони навколишнього природного середовища $[4,5,6]$.

Методологічні основи державного стимулювання природокористування, основні показники стимулюючої діяльності та організаційна структура її здійснення досліджені в роботах $[7,8,9,10]$.

Виділення невирішених раніше частин загальної проблеми. Слід зазначити, що питання державного регулювання стимулювання екологоорієнтованого бізнесу на основі проведення тендерів практично не вивчалися.

Формулювання цілей дослідження. Метою дослідження $є$ розробка наукових підходів проведення екологічних тендерів стимулювання розвитку підприємницької діяльності.

Виклад основних результатів та їх обгрунтування. Екологічний тендер може бути двох видів в залежності від того, хто виступає в ролі покупця товару, послуги, роботи (замовника), а хто в ролі продавця (при цьому і той і інший зобов'язуються виконувати свою роботу відповідно до базової або договірної програми відповідно до договору - зобов'язанням). Зазвичай замовниками екологічного тендера виступають органи виконавчої влади та органи місцевого самоврядування, а також підпорядковані їм установи та організації.

Екологічний тендер відрізняється від бірж, де одночасно беруть участь багато продавців і багато покупців одного і того ж товару (послуги, роботи), інтереси яких захищають брокери. На тендерах брокерів немає, і кожен торг передбачає звести разом одного покупця з декількома потенційними продавцями. Тому завдання тендера зводиться до того, щоб забезпечити замовнику можливість вибору одного з варіантів пропозиції за такими критеріями, як ціна, але з урахуванням екологічних складових або інтерналізації зовнішніх витрат ресурсо-товару, ряд техніко-економічних і екологічних параметрів.

Специфіка екологічних торгів полягає в тому, що розглянута тендерним комітетом ціна, повинна враховувати альтернативну вартість природного ресурсу. Альтернативна вартість - це потенційна віддача від кращого з усіх тих варіантів використання природного ресурсу, які були принципово можливі, але залишилися невикористаними. В економіці природокористування ці вартості дозволяють оцінити природний об'єкт або ресурс, що мають занижену або взагалі не мають ринкову ціну, через втрачені доходи і вигоди, які можна було б отримати при використанні даного об'єкта або ресурсу в інших цілях. Чим менше альтернативна вартість природного блага, тим менше потрібно витрат для компенсації економічних втрат від збереження цього блага. При визначенні ціни проекту,

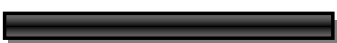

128
Економічні інновації

Випуск №65 
використовуваного ресурсу, товару, послуги і роботи екологічного тендера слід розрізняти поняття економічної цінності природного ресурсу і його ціни. Економічна цінність охоплює всі три функції ресурсу, а в ціні ж фактично відбивається тільки його перша природна функція - оцінка природного ресурсу. Якщо відбувається збіг ціни і оцінки (цінністю) природного ресурсу, тоді функціонування економіки, співвідношення попиту i пропозиції, поведінка споживачів будуть враховувати екологічний фактор. В цьому відношенні позитивним $є$ поява ринків нових товарів (ресурсів) $\mathrm{i}$ послуг, пов'язаних з відсутніми в даний час цінами на природні функції [10].

Однією з важливих причин втрати природних ресурсів, збільшення природоємності економіки стало перевищення ваги реальних економіко-екологічних збитків і допустимих нормативів екологічного податку, який визначається за Податковим кодексом України.

Облік ціни / оцінки природних ресурсів дозволить більш обгрунтовано визначити економічну ефективність альтернатив стимулювання. Доцільно включати оцінку стимулювання розвитку екологоорієнтованого бізнесу в приріст національного багатства країни на основі природних складових. До сих пір цього не робиться, що зайвий раз свідчить про недооцінку механізмів стимулювання раціонального використання природних ресурсів. Тим часом ця оцінка $\epsilon$ важливою складовою збільшення національного багатства, відображаючи природний потенціал країни i зберігаючи критичний природний капітал. Не досліджувалась раніше: які витрати несе держава на стимулювання природоохоронної діяльності та який вона отримує результат. Витрати держави на стимулювання природоохоронних заходів виражаються в зниженні податків, у встановленні податкових канікул, що веде в підсумку до недоотримання коштів державним і місцевими бюджетами. Природний потенціал поряд 3 громадським багатством (накопиченими виробничими $\mathrm{i}$ невиробничими фондами) багато в чому визначає розвиток народного господарства на перспективу. Тендер сприяє формуванню конкурентного середовища для підприємств, які потребують державного стимулювання природоохоронної діяльності, що проявляється в удосконаленні державної системи управління стимулюванням природокористування, а саме:

- концентрація державних та приватних фінансових потоків на пріоритетних напрямках охорони, відновлення і відтворення природних ресурсів в країні і регіонах,

- зниження розпилення державних коштів, що спрямовуються на стимулювання екологоорієнтованого бізнесу,

- стимулювання об'єктів виробничо-господарської діяльності, які потребують удосконалення техніко-технологічного процесу для збереження навколишнього середовища,

- контроль за виконанням умов тендера і гнучке реагування на відхилення від умов стимулювання,

- мотивація суб'єктів до цільового використання отриманих від держави коштів на природоохоронні цілі.

Суть державного тендеру щодо стимулювання екологоорієнтованого бізнесу полягає в тому, що на тендер виходять підприємства різних районів України та їх завдання полягає в переконанні держави в необхідності і економіко-екологічної доцільності виділення їм коштів для стимулювання природоохоронної діяльності. Процес цей непростий, і вимагає ретельного попереднього вивчення всього ринку попиту на державне стимулювання (відповідно до закону України «Про охорону навколишнього природного середовища» [4]. Тому торги, починаючи з моменту публікації про них, можуть тривати більше місяця. Рішення про проведення приймається замовником - спеціально уповноваженими державними органами Міністерства економіки та торгівлі України і Міністерства фінансів України. Після затвердження рішення в установленому порядку здійснюється технікоекономічне та економіко-екологічне обгрунтуваня умов стимулювання і тендерної документації, їх узгодження 3 чинним законодавством і відповідними органами державної влади $\mathrm{i}$ місцевого самоврядування, а також з урахуванням матрично-рейтингового підходу до розподілу державних фінансових коштів по регіонах і природним об'єктам забруднення.

При розгляді програм державного стимулювання генеральним замовником може бути - орган державної влади, місцеві державні адміністрації або виконавчі органи місцевих рад відповідальні за організацію і проведення процедур тендеру на принципах координації відповідно до цього Закону України.

Метою проведення таких тендерів екологічного спрямування на укладання контрактів на стимулювання раціонального використання природних ресурсів i охорони навколишнього

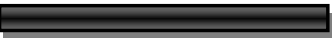

2017
Економічні інновації

Випуск №65
E

129 
природного середовища $є$ залучення коштів іноземних та вітчизняних інвесторів для забезпечення ефективного і раціонального використання даного ресурсу із застосуванням новітніх технологій, створення вигідних для держави умов укладення контрактів на користування природними ресурсами 3 подальшим оформленням і отриманням спеціальних дозвільних документів.

Торги повинні бути тільки відкритими, в яких беруть участь претенденти всіх форм власності. Після прийняття Кабінетом Міністрів України рішення про проведення тендера його замовник створює тендерний комітет у складі уповноважених представників зацікавлених міністерств, інших центральних i місцевих органів виконавчої влади, і представників громадянського суспільства. Тендерний комітет контролює хід роботи, пов'язаної з проведенням державного тендеру щодо стимулювання екологоорієнтованого бізнесу, стверджує тендерну документацію та результати тендеру, остаточно узгоджує умови контракту з переможцем тендеру.

Відповідність претендента економіко-екологічним вимогам, за якими здійснюється його стимулювання, визначається тендерним комітетом (державні службовці та представники громадськості, особи, що проживають в даному регіоні) на підставі оцінки поданого ним пакету документів.

До участі в державному тендері стимулювання природоохоронної діяльності не допускаються наступні претенденти:

- діяльність яких не відповідає економіко-екологічним вимогам територій України, і при цьому вони мають всі необхідні засоби для здійснення природоохоронних заходів;

- підприємства, яким раніше були виділені кошти на природоохоронні заходи, але вони їх не освоїли в термін за цільовим призначенням;

- підприємства, які визнані банкрутами або щодо яких порушено справу про банкрутство;

• підприємства які подали разом із заявкою на участь в тендері неправдиву економіко-екологічну інформацію тощо.

Умови тендеру затверджуються тендерним комітетом до оголошення про тендер $\mathrm{i} \epsilon$ обов'язковими для виконання його учасниками. Під час вивчення, оцінки заявки на участь в тендері, тендерний комітет має право вимагати від претендентів додаткову економіко-екологічну інформацію, яка характеризує можливість учасників тендера освоювати виділені державою кошти на природоохоронні заходи, передбачені тендерною документацією.

Рішення тендерного комітету має прийматися на засіданнях з представниками громадськості, що складається 3 професіоналів в сфері економіки природокористування та охорони навколишнього природного середовища та людей, що проживають в даному регіоні.

Положення про порядок організації та проведення конкурсних екологічних торгів (тендерів) щодо стимулювання природоохоронної діяльності передбачає укладання контрактів між державним органом, який виділяє кошти на стимулювання розвитку екологоорієнтованого бізнесу i підприємством, яке отримує гроші 3 умовами їх подальшого цільового освоєння за термінами $\mathrm{i}$ певним заходам.

Організація державного тендеру стимулювання природоохоронної діяльності включає такі основні напрямки:

1. Розміщення в засобах масової інформації оголошення замовника тендера із запрошенням претендентів взяти в ньому участь. Так, наприклад, держава може виділити певну суму коштів по областям, яку вона заявляє в пресі. Всі підприємства, які претендують на отримання даних коштів 3 метою здійснення природоохоронних заходів, можуть заявити про свої наміри участі в тендері державного стимулювання природоохоронної діяльності. До оголошення про проведення процедури дозвільної діяльності на об'єкті тендеру може здійснюватися процедура попередньої кваліфікації виконавців. За результатами проведення процедури попередньої кваліфікації визначається відповідність вимогам, які висуває тендерний комітет. Тільки ті виконавці, які пройдуть такий попередній відбір, допускаються до подальшої участі.

Замовник, протягом певного часу від дня отримання запиту про надання необхідних документів, направляє учасникам тендеру таку тендерну документацію:

- інструкцію щодо підготовки тендерних документів;

- перелік критеріїв, які висуваються тендерним комітетом 3 метою оцінки відповідності виконавців встановленим кваліфікаційним вимогам;

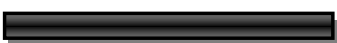

130
Економічні інновації

Випуск №65

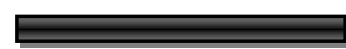

2017 
- інформацію про характер і необхідні якісні характеристики, які повинні бути досягнуті в результаті ос воєння, виділених державою коштів на охорону навколишнього природного середовища;

• перелік критеріїв та методику їх оцінки для визначення найкращої тендерної пропозиції;

- зазначення основних умов, які обов'язково будуть включені до договору-контракт;

- спосіб оцінки і порівняння альтернативних тендерних пропозицій;

- вимоги замовника щодо надання тендерного забезпечення;

- умови повернення або неповернення коштів, виділених державою на стимулювання екологоорієнтованого бізнесу;

- зазначення способу, місця та кінцевого терміну подання тендерних пропозицій;

• визначення процедури надання роз'яснення щодо тендерної документації тощо.

2. Подача пропозицій учасниками. Тендерна пропозиція екологічного спрямування: на цільові природоохоронні та організаційні роботи, щодо реалізації Державних програм на проведення заходів щодо раціонального використання природного потенціалу територій, на проведення робіт 3 проектування природоохоронного устаткування, на виконання робіт щодо введення в експлуатацію полігону твердих відходів, для проведення робіт по посадці і реконструкції лісових насаджень тощо. Пропозиції подаються щодо певного предмета послуг та виду діяльності, яка готується та направляється виконавцем замовнику відповідно до вимог тендерної документації та нормативноправової екологічної документації. Забезпечення тендерної пропозиції - це надання виконавцем замовнику гарантій щодо забезпечення виконання ним зобов'язань, які виникають у зв'язку 3 поданням тендерних пропозицій.

3. Вибір переможця торгів. Рішення тендерного комітету приймаються на закритих засіданнях у присутності не менше двох третин його складу відкритим голосуванням простою більшістю голосів. Перевіряється наявність усіх необхідних документів, правильність їх оформлення, оголошується сума фінансового стимулювання для кожної тендерної пропозиції на підставі критеріїв оцінки 3 урахуванням екологічної складової та природних особливостей регіону.

До критеріїв оцінки доцільності виділення державних коштів для стимулювання природоохоронної діяльності повинні бути віднесені:

• комплексна економіко-екологічна оцінка впливу запланованої або здійснюваної діяльності на стан навколишнього природного середовища, використання і відтворення природних ресурсів, здоров'я населення, в результаті освоєння державних коштів;

- матрично-рейтинговий підхід до розподілу державних фінансових коштів по регіонах і природним об'єктам забруднення:

- забезпечення комплексної переробки, утилізації і ефективного використання відходів виробництва;

- заходи щодо економії водних ресурсів, забезпечення ефективної очистки всіх видів стічних вод;

- заходи з охорони атмосферного повітря від забруднення;

- забезпечення схоронності, охорони і відтворення об'єктів рослинного і тваринного світу та природно-заповідного фонду;

- забезпечення захисту населення і навколишнього природного середовища від шкідливого впливу антропогенних фізичних, хімічних і біологічних факторів тощо.

Слід використовувати також при аналізі проектів / програм альтернативні проекти. Це варіант застосування підходу на основі компенсуючих витрат, в якому досліджують потенційні витрати для заміщення втраченого або пошкодженого ресурсу ідентичним в альтернативному місці. Альтернативний проект, таким чином, фізично відшкодовує втрату ресурсів. Для проведення оцінки тендерних пропозицій замовником можуть залучатися експертні організації або окремі фахівці.

Після всебічного розгляду пропозицій, що надійшли, оголошується переможець або переможці торгів, з яким замовник укладає контракт.

Сума стимулювання включає загальні витрати на утримання комітету з тендером, тому дуже важливим є зниження витрат управління даного комітету. При визначенні трансакційних витрат управління слід враховувати тендерним комітетом трансакційні витрат: ex-ante до проведення екологічного тендера, так i ex-post - після. До витрат типу ex-ante відносяться витрати на складання проекту угоди та проведення переговорів щодо нього. Витрати типу ex-post включають в себе організаційні та експлуатаційні витрати, пов'язані з використанням структури управління; витрати,

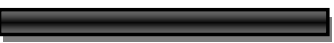

2017
Економічні інновації

Випуск №65
E 
що виникають через погану адаптацію; витрати на позови, що виникають в ході пристосування контрактних відносин до непередбачених обставин; витрати, пов'язані з виконанням контрактних зобов'язань.

Принципами здійснення державних тендерів по стимулюванню природоохоронної діяльності, що проводиться екологоорієнтованого бізнесом, є:

- добросовісна конкуренція серед учасників;

- максимальна економія та ефективність;

- відкритість і прозорість на всіх стадіях;

- недискримінація учасників;

• об'єктивна та неупереджена оцінка пропозицій конкурсних торгів;

- запобігання змови, корупційних дій і зловживань.

Залежно від способу проведення державні торги, щодо стимулювання підприємств екологоорієнтованого бізнесу, бувають:

- відкритими;

• відкритими з попередньою кваліфікацією;

- торги з обмеженою участю;

- двоступеневі торги;

• процедури запиту за обсягами фінансування стимулювання.

Торги 3 обмеженою участю проводяться в разі, якщо державі необхідно запровадити певні екологічно чисті технології, які через їх складний або спеціалізований характер можуть бути запропоновані обмеженому колу виконавців; якщо роботи, послуги, під які виділяються державні гроші, в зв'язку з їх спеціалізованим призначенням, є державною таємницею (це може стосуватися екологічних програм, а також нових екологічних технологій). Кількість виконавців має бути не менше двох.

Двоступеневі державні торги щодо стимулювання природоохоронного бізнесу складаються 3 наступних етапів:

- Перший етап: всім виконавцям пропонується подавати тендерні пропозиції без сум запитуваного державного стимулювання. Після цього замовник проводить з ними переговори.

- Другий етап: виконавцям, попередні пропозиції яких не були відхилені, пропонується надати остаточні тендерні пропозиції із зазначенням сум запитуваного державного стимулювання (після цього процедура вже нічим не відрізняється від відкритих торгів).

Процедури запиту за обсягами фінансування стимулювання - відбувається на основі розроблених бізнес-планів здійснення природоохоронної діяльності.

Організацією екологічних торгів, як правило, займаються досвідчені консультаційні фірми. При проведенні державних тендерів екологічного спрямування функції спеціалізованих (консультаційних) фірм можуть брати на себе місцеві органи влади, які є юридичними «господарями» природних ресурсів і території регіону, наукові колективи.

Фінансування проведення тендера здійснюється за рахунок державних коштів і коштів претендентів, які хочуть взяти участь в тендері. Розмір плати за участь у тендері визначається робочою групою і затверджується тендерним комітетом разом 3 кошторисом на організацію i проведення тендеру. Ці кошти надходять на окремий рахунок замовника тендера і використовуються на оплату повідомлень в пресі, оренду приміщень, відряджень, зв'язку, розробка, узгодження, розмноження, перекладу документації, проведення переговорів, конференцій і т.п. При виявленні порушень порядку проведення торгів їх результати вважаються недійсними. Спори, що виникають в результаті торгів, розглядаються арбітражними судами України.

В кінцевому підсумку головне завдання полягає в забезпеченні освоєння державних коштів, виділених на стимулювання розвитку екологоорієнтованого бізнесу, що забезпечує раціональне використання та охорону природних ресурсів держави.

Для створення потужного економічного і природного базису України державне стимулювання екологоорієнтованого бізнесу має сприяти швидкому і якісному впровадженню і виробництву екологічно чистих і екологобезпечних товарів, послуг, робіт на базі новітніх технологій і сучасних наукових досягнень, розвитку вільного підприємництва.

При проведенні, особливо, державних торгів стимулювання природоохоронних заходів, повинна залучатися громадськість. Громадський контроль забезпечується через вільний доступ до всієї інформації про проведення тендерів, які підлягають оприлюдненню відповідно до Закону України

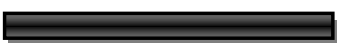

132
Економічні інновації

Випуск №65 
про тендери. Замовники і учасники процедур повинні сприяти залученню громадськості до здійснення контролю у сфері природокористування. Громадяни та громадські організації та їх спілки не мають права втручатися в діяльність Уповноваженого органу та в процедуру визначення замовником переможця торгів. Під час проведення процедур розкриття пропозицій конкурсних торгів мають право бути присутніми представники засобів масової інформації. Замовники зобов'язані забезпечити безперешкодний доступ представників засобів масової інформації на їхню вимогу до процедури розкриття пропозицій конкурсних торгів.

Висновки та перспективи подальших досліджень. Розподіл продуктивних сил в країні, 3 розвитком промислово-виробничого потенціалу, який при даному рівні технологій не може забезпечити повністю екологічно чисте виробництво, слід стимулювати в напрямку впровадження екологоорієнтованого бізнесу. В даний час технології, що зберігають природне середовище $\epsilon$ дорогими для суб'єктів підприємницької діяльності, тому необхідна підтримка з боку держави в перерозподілі фінансових коштів в залежності від ступеня антропогенного впливу на навколишнє природне середовище. Виділення фінансових коштів з боку держави має бути компенсацією соціоекономіко-екологічного збитку, який зумовлений вже існуючим розміщенням продуктивних сил.

Тому авторський підхід до стимулювання екологоорієнтованого бізнесу повинен грунтуватися на проведенні екологічних тендерів, де будуть виділені підприємства, які потребують фінансової підтримки, що буде відповідати сучасному рівню розвитку продуктивних сил нашої країни. Впровадження тендера в практику стимулювання екологоорієнтованого бізнесу дозволить суб'єктам підприємницької діяльності оновити основні виробничі фонди, оборотні кошти, впровадити екологічно чисті технології, перейти на інноваційні процеси розвитку економіки і поліпшити екологічну ситуацію в країні.

\section{ЛІТЕРАТУРА}

1. Положение о порядке организации и проведения международных торгов (тендеров) в сфере государственных закупок товаров (работ, услуг) иностранного происхождения : Постановление Кабинета Министров Украины от 28 июня 1997 года № 694. [Електронний ресурс]. - Режим доступу: http://consultant.parus.ua/?doc=0058A73A37

2. Про здійснення державних закупівель : Закон України від 30.07.2010 [Електронний ресурс]. Режим доступу: laws.tendergid.ua

3. Положение о порядке организации и проведения международных конкурсов (тендеров) на заключение контрактов на пользование недрами [Електронний ресурс]. - Режим доступу: http://base.spinform.ru/show_doc.fwx?rgn=14355

4. Про охорону навколишнього природного середовища : Закон України [Електронний ресурс]. Режим доступу: http://zakon0.rada.gov.ua/laws/show/1264-12.

5. Колотырин К.П. Экономические инструменты стимулирования природоохранной деятельности [Електронний ресурс]. - Режим доступа: http://cyberleninka.ru/article/n/ekonomicheskieinstrumenty-stimulirovaniya-prirodoohrannoy-deyatelnosti.

6. Сарабський І.А. Економічне стимулювання охорони довкілля [Електронний ресурс]. - 2007. № 10. - С. 128-129. - Режим доступу: http://www.fundamental-research.ru/ru/article/view?id=4557

7. Нікола С.О. Організаційна структура державного стимулювання екологоорієнтованого бізнесу / С.О. Нікола // Економічні інновації: зб. наук. праць. - Одеса, 2017. - Вип. 63. - С. 183-190.

8. Нікола С.О. Показники системи економічного стимулювання природокористування в умовах екологізації підприємницької діяльності / С.О. Нікола // Економічні інновації: зб. наук. праць. Одеса, 2016. - Вип. 62. - С. 338-344

9. Никола С.О. Методологические основы государственного стимулирования природопользования [Електронний ресурс] / С. О. Никола // Економіка та суспільство. - Мукачево, 2016. - Вип. №5. - С. 288-293. - Режим доступа: http://economyandsociety.in.ua

10. Садченко О.В. Інноваційно-екологічне управління у рекреаційно-туристичному природокористуванні приморських регіонів України / О.В. Садченко // Економічні інновації: зб. наук. праць. - Одеса, 2016. - Вип. 62. - С. 176-181

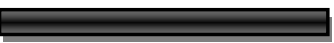

Економічні інновації

Випуск №65
E

133 


\section{REFERENCES}

1. Polozhennia pro poriadok orhanizatsii ta provedennia mizhnarodnykh torhiv (tenderiv) u sferi derzhavnykh zakupivel' tovariv (robit, posluh) inozemnoho pokhodzhennia : Postanova Kabinetu Ministriv Ukrayiny vid 28 chervnia 1997 roku \# 694 [Regulation on the procedure for the organization and conduct of international tenders in the sphere of state procurement of goods (works, services) of foreign origin: Decree of the Cabinet of Ministers of Ukraine dated June 28, 1997 No. 694]. consultant.parus.ua/?doc $=0058$ A73A37 Retrieved from: http://consultant.parus.ua/?doc=0058A73A37

2. Pro zdiysnennia derzhavnykh zakupivel' : Zakon Ukrayiny 30.07.2010 [On the Procurement: Law of Ukraine dated July 30, 2010]. laws.tendergid.ua - Retrieved from: http://laws.tendergid.ua

3. Polozhennia pro poriadok orhanizatsiyi ta provedennia mizhnarodnykh konkursiv (tenderiv) na ukladannia kontraktiv na korystuvannia nadramy [Regulations on the procedure for organizing and conducting international competitions (tenders) for the conclusion of contracts for the use of subsoil] base.spinform.ru/show_doc.fwx? rgn=14355. - $\quad$ Retrieved from: http://base.spinform.ru/show_doc.fwx?rgn=14355

4. Pro okhoronu navkolyshnioho pryrodnoho seredovyshcha : Zakon Ukrainy [On Environmental Protection: The Law of Ukraine]. zakonO.rada.gov.ua/laws/show/1264-12 - Retrieved from: http://zakon0.rada.gov.ua/laws/show/1264-12.

5. Kolotyrin, K.P. Ekonomicheskiie instrumenty stimulirovaniia prirodookhrannoi deiatel'nosti [Economic instruments for stimulating environmental activities]. cyberleninka.ru/article/n/ekonomicheskieinstrumenty-stimulirovaniia -prirodoohrannoy-deia telnosti - Retrieved from: http://cyberleninka.ru/article/n/ekonomicheskie-instrumenty-stimulirovaniia -prirodoohrannoy-deia telnosti [in Russian].

6. Sarabs'kyi, I.A. (2007) Ekonomichne stymuliuvannia okhorony dovkillia [Economic stimulation of environmental protection]. $w w w$. fundamental-research.ru/ru/article/view?id=4557. 10, 128-129. - Retrieved from: http://www.fundamental-research.ru/ru/article/view?id=4557

7. Nikola, S.O. (2017) Orhanizatsiina struktura derzhavnoho stymuliuvannia ekolohooriientovanoho biznesu [Organizational structure of state incentives for ecologically oriented business]. Ekonomichni innovatsii - Economic innovation. Odesa. 63, 183-190 [in Ukrainian].

8. Nikola, S.O. (2016) Pokaznyky systemy ekonomichnoho stymuliuvannia pryrodokorystuvannia v usloviiakh ekolohizatsii pidpryiemnits'koi diial'nosti [Indicators of the system of economic incentives for environmental use in conditions of environmentalization of entrepreneurial activity]. Ekonomichni innovatsii - Economic innovation. Odesa. 62, 338-344

9. Nikola, S.O. (2016) Metodolohichni osnovy derzhavnoho stymuliuvannia pryrodokorystuvannia [Methodological bases of state stimulation of nature management]. Ekonomika ta suspil'stvo - Economics and Society. Mukachevo. 5, 288-293. economia ndsociety.in.ua - Retrieved from: http://economia ndsociety.in.ua

10. Sadchenko, O.V. (2016) Innovatsiyno-ekolohichne upravlinnia u rekreatsiyno-turystychnomu prirodokoristuvanni Prymors'k rehioniv Ukrayiny [Innovative-ecological management in recreational and tourist use of seaside regions of Ukraine]. Ekonomichni innovatsii - Economic innovation. - Odesa. 62, 176181

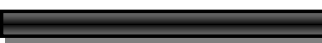

134
Економічні інновації

Випуск №65 